\title{
Bioleaching of fluoride-containing uranium: flask experiments with fluoride-resistant bacteria
}

\author{
Xiang Li ${ }^{1, a}$, Xiaolan $\mathrm{Mo}^{1, \mathrm{~b}}$, Jiankang Wen ${ }^{1, \mathrm{c}}$, Biao $\mathrm{Wu}^{1, \mathrm{~d}}$, Dianzuo Wang ${ }^{1, \mathrm{e}}$, \\ Hongying Yang ${ }^{2, f}$
}

${ }^{1}$ National Engineering Laboratory of Biohydrometallurgy, General Research Institute for Nonferrous Metals, Beijing 100088, China

${ }^{2}$ School of metallurgy, Northeastern University, Shenyang 110891, China

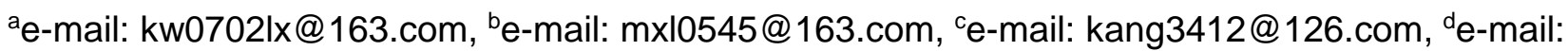
angelwbiao@sina.com, ee-mail:wu_ml_7483@163.com, ${ }^{\mathrm{f}} \mathrm{e}-\mathrm{mail}$ : yanghy@smm.neu.edu.cn

Keywords: Uranium; fluoride; bioleaching

Abstract. The results of MLA automated quantitative mineralogy system indicated the uranium ore used in this study was mainly composed of pitchblende(1.026), aluminosilicate(include biotite $(31.72 \%)$, albite(13.98\%) and orthoclase(13.43\%)), and fluorite(0.94\%). The fluoride-resistant bacteria strain could growth normally under the condition of fluoride ion concentration as high as $600 \mathrm{mg} / \mathrm{L}$. The uranium extration rate of bioleaching flask reached $74 \%$ in 10 days, bioleaching have obvious advantages compare to conventional acid leaching (46\%).

\section{Introduction}

Utilizing of low grade uranium ores is a great challenge with the depletion of high-grade uranium ores and the increasing demand of nuclear energy for uranium material[1,2]. Bioleaching is a well-established technology and an alternative to conventional pyrometallurgical processes for the treatment of uranium[3,4]. It has many advantages such as adaptation to low-grade ores, short leaching cycle, relatively low cost and low contamination. For the fluoride-containing uranium, the application of bioleaching was limited. As a strong hydrogen bonding species, fluoried could enter into the cell by species of HF and affect bacterial metabolism[5]. Therefore, the microbiological shake flask test was selected to test the domestication effect of fluoride-resistant bacteria. Explored the test cycle, acid consumption and leaching rate to provide scientific basis for the mining of fluorine-containing uranium ore, and to provide process parameters for industrial heap leaching production.

\section{Materials and methods}

Ore samples. Bioleaching experiments were carried out with the uranium ore samples, the chemical analyses of these are listed in Table 1.

Table 1: Chemical analysis $(\%)$ of the ore samples studied

\begin{tabular}{ccccccccc}
\hline $\mathrm{Si}$ & $\mathrm{Al}$ & $\mathrm{Fe}$ & $\mathrm{Ca}$ & $\mathrm{Ti}$ & $\mathrm{K}$ & $\mathrm{Zr}$ & $\mathrm{Mg}$ & $\mathrm{S}$ \\
\hline 30.7 & 9.38 & 3.434 & 2.1 & 0.375 & 3.34 & 0.023 & 0.772 & 0.382 \\
\hline $\mathrm{Na}$ & $\mathrm{Mn}$ & $\mathrm{P}$ & $\mathrm{Mo}$ & $\mathrm{Th}$ & $\mathrm{Y}$ & $\mathrm{F}$ & $\mathrm{U}$ & $\mathrm{Sr}$ \\
\hline 0.361 & 0.055 & 0.293 & 0.114 & 0.079 & 0.022 & 0.516 & 0.234 & 0.021 \\
\hline
\end{tabular}

A mineralogical analysis was previously performed using MLA and scanning electron microscopy-energy dispersive spectroscopy (SEM-EDS) (table 2). The mainly uranium-contained minerals were pitchblende $(1.026 \%)$, brannerite $(0.314 \%)$, coffinite $(0.070 \%)$; Other mainly sulfides metal were pyrite $(1.454 \%)$ and a small amount of galena, sphalerite, arsenopyrite, etc ; Mainly oxides metal was hematite $(0.140 \%)$; Non-metallic gangue minerals were accounted for more than $90 \%$ of the ore samples. Mainly gangue minerals were biotite (31.757\%) and quartz (27.724\%), followed by 
albite $(13.975 \%)$ and orthoclase (13.425\%). Alkaluminite minerals were account for more than $64 \%$ of the ore samples.

Table 2 Mineral composition and relative content of the uranium ore

\begin{tabular}{cccc}
\hline Mineral & Wt\% & Mineral & Wt\% \\
\hline Coffinite & 0.070 & Biotite & 31.757 \\
Pitchblende & 1.026 & Albite & 13.975 \\
Brannerite & 0.314 & Orthoclase & 13.425 \\
Thorite & 0.132 & Anorthite & 0.160 \\
Pyrite & 1.454 & Hedenbergite & 0.087 \\
Galena & 0.101 & Apatite & 1.595 \\
Hematite & 0.140 & Garnet & 0.291 \\
Quartz & 27.724 & Wollstonite & 0.005 \\
Fluorite & 0.940 & Kaoline & 0.018 \\
Calcite & 1.280 & Rutile & 0.177 \\
Dolomite & 0.241 & Other & 0.097 \\
\hline
\end{tabular}

Bacteria. The fluorine-tolerance bacteria used in this study were obtained from National Engineering Laboratory of Biohydrometallurgy (China),named NFCJ-6 strains, composed of At. ferrooxidans and Acidiphilium sp. Bacterial growth was carried out in the $9 \mathrm{~K}$ medium $(3 \mathrm{~g} / \mathrm{L}$ $\left(\mathrm{NH}_{4}\right)_{2} \mathrm{SO}_{4}, 0.5 \mathrm{~g} / \mathrm{L} \mathrm{MgSO}{ }_{4} \cdot 7 \mathrm{H}_{2} \mathrm{O}, 0.5 \mathrm{~g} / \mathrm{L} \mathrm{K}_{2} \mathrm{HPO}_{4}, 0.1 \mathrm{~g} / \mathrm{L} \mathrm{KCl}, 0.01 \mathrm{~g} / \mathrm{L} \mathrm{Ca}\left(\mathrm{NO}_{3}\right)_{2}$ and $44.2 \mathrm{~g} / \mathrm{L}$ $\mathrm{FeSO}_{4} \cdot 7 \mathrm{H}_{2} \mathrm{O}$,).

Bioleaching experiments. The fluoride-containg uranium leaching experiments were carried out in $250 \mathrm{ml}$ conical flask, shake flasks in a temperature-controlled incubator that was held at $30 \pm 1^{\circ} \mathrm{C}$, $160 \mathrm{rpm}$. Two sets of shake flask tests were set up, one for microbial leaching and the other one for acid leaching. The leaching system is $80 \mathrm{~mL}$ of iron-free $9 \mathrm{~K}$ medium with a liquid to solid ratio of 4:1 ( $80 \mathrm{~mL}$ of solution: $20 \mathrm{~g}$ of ore). Bioleaching flasks was inoculated in the 6 th day of testing with the fluoride-resistant strain. the pregnant leach solution(PLS) collected of each flask had liquor aliquots withdrawn for subsequent analyses(i.e. measurement of the $\mathrm{pH}, \mathrm{Eh}$, bacterial counts and analysis of the elements concentration). Subsequently, the PLS volume was recorded and this was then used in uranium extraction calculations. Analyses and evaporation losses were compensated with distilled water. After the $\mathrm{pH}$ was adjusted with dilute $\mathrm{H}_{2} \mathrm{SO}_{4}\left(\mathrm{H}_{2} \mathrm{SO}_{4}: \mathrm{H}_{2} \mathrm{O}=1: 1\right)$.

\section{Results and discussion}

Profile of $\mathbf{p H}$ and acid consumption. One of the key parameters in bioleaching operations is the $\mathrm{pH}$ of the solution. Whilst higher acidities are important for mineral dissolution, the $\mathrm{pH}$ must be set at values that simultaneously ensure an optimum bacterial growth rate and high concentrations of ferric iron in solution.

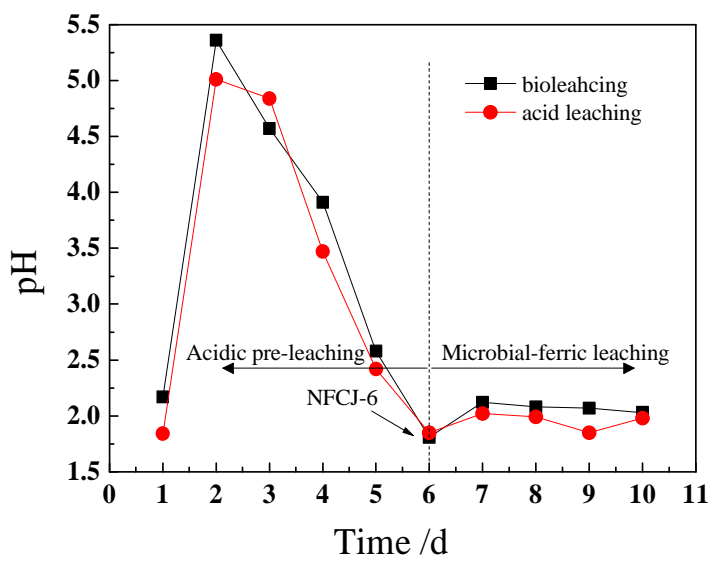

Fig.1 The pH dynamic variation in the leaching solution during leaching of uranium 
The $\mathrm{pH}$ value of $2.00 \pm 0.05$ was selected in this study, because of above a $\mathrm{pH}$ of 2.5 , the ferric iron will forms in jarosite precipitation and lose the oxidation activity. As shown in Fig.1, after the acidification of the ore in the column with a dilute sulfuric acid solution for 6 days, the $\mathrm{pH}$ was reduced to about 2.0, which created the best conditions for subsequent microbial leaching. In the 6-day pre-soaking stage, the sulphuric acid consumption reached $62.02 \mathrm{~kg} / \mathrm{t}$ ore(bioleaching) and $64.00 \mathrm{~kg} / \mathrm{t}$ ore (acid leaching).

Dissolution of gangue elements. Gangue minerals, in addition to acid consumption, account for the presence of elements in the leachate, that may affect bacterial growth, dependent on nature and concentrations of those elements. Thus, from a metallurgical and bacterial viewpoint, the profile of the most critical species must be assessed. Aluminum- and fluoride-bearing minerals were detected during mineral characterization and the content of these in both samples was fairly high (Tab.1). The anion is harmful to acidophilic bacteria and the presence of both in the leachate was due to the solubility of fluorite and apatite in acidic media.In the first 6 days of leaching, aqueous fluoride concentrations were mostly exceed $600 \mathrm{mg} / \mathrm{L}$ (Fig.2), which were significantly impair ferrous iron bio-oxidation. This is a very high concentration, given the low fluoride tolerance reported for $A t$. ferrooxidans, i.e. bacterial growth was shown to be severely hampered for concentrations above 20 $\mathrm{mg} / \mathrm{L}$ fluoride [6]. In bioleaching sysytem, after adding the NFCJ-6 strain, the concentration of $\mathrm{F}^{-}$in the solution dropped significantly, and the concentration of $\mathrm{F}^{-}$in the solution dropped to $450 \mathrm{mg} / \mathrm{L}$ after 1 day. After 3 days, the concentration of $\mathrm{F}^{-}$in the solution was almost undetectable. It is due to the fact that $\mathrm{Fe}^{3+}$ produced by bacterial growth completely complex with $\mathrm{F}^{-}$in the solution. The results showed that the fluoride-resistant strains had obvious effects on fluoride tolerance, and the bacteria still had high iron oxidizing ability in the high-fluorine environment. In the acid leaching test, after 6 days of acidic leaching, the concentration of $\mathrm{F}^{-}$in the solution also showed a tendency to decrease, but the amplitude was smaller and only decreased less than $100 \mathrm{mg} / \mathrm{L}$. It is because that the aluminosilicate gangue minerals slightly dissolve out of $\mathrm{Al}^{3+}$ during the leaching process and complex a portion of the $\mathrm{F}^{-}$, resulting in a decrease of the concentration of $\mathrm{F}^{-}$.

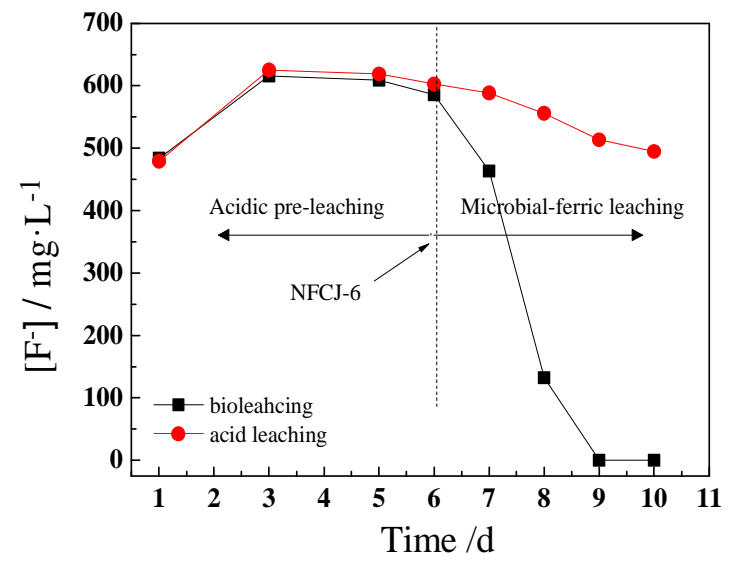

Fig.2 The variation of $\mathrm{F}^{-}$during leaching of uranium

Solution potential and iron profile. The solution potential is affected by ferric iron produced by the bacteria and is therefore related to the bacterial population present in the system. 

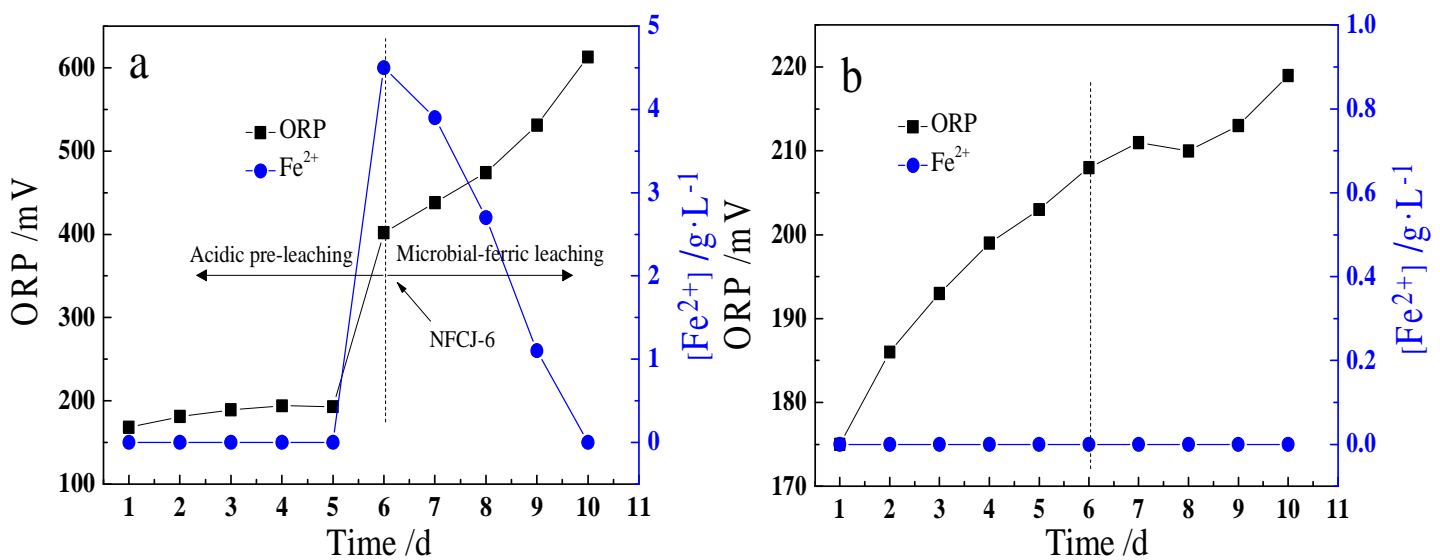

Fig.3 The variation of Eh and iron concentration in leaching process (a: bioleaching; B: acid leaching)

This can be seen in Fig. 3 which shows significantly higher Eh values in all of the inoculated flask as compared to the non-inoculated tests. In the context of bioleaching, the solution potential is defined by the activities of ferrous and ferric iron in the leachate; thus, the Fetot concentration profile is shown in Figure 1(c). The inoculated columns demonstrated higher concentrations of soluble iron $(4 \mathrm{~g} / \mathrm{L})$ than it detected in the non-inoculated flask.

Uranium extractions. Despite the high fluoride concentrations depicted in Fig.3, uranium dissolution was slow and leaching rate can be achieved $40 \%$ around(both bioleaching flask and acid leaching flask) at the acidic pre-leaching stage. At later acidic pre-leaching stage, the dynamic of uranium leaching was insufficient, as the leaching rate of $5^{\text {th }}$ and $6^{\text {th }}$ were similar. After leaching for 10 days, the leaching rate of uranium ore by biological leaching was $74.71 \%$, while that by acid leaching was only $46.61 \%$. The test results show that the leaching rate of leaching uranium by microbial leaching is increased by $28.1 \%$.

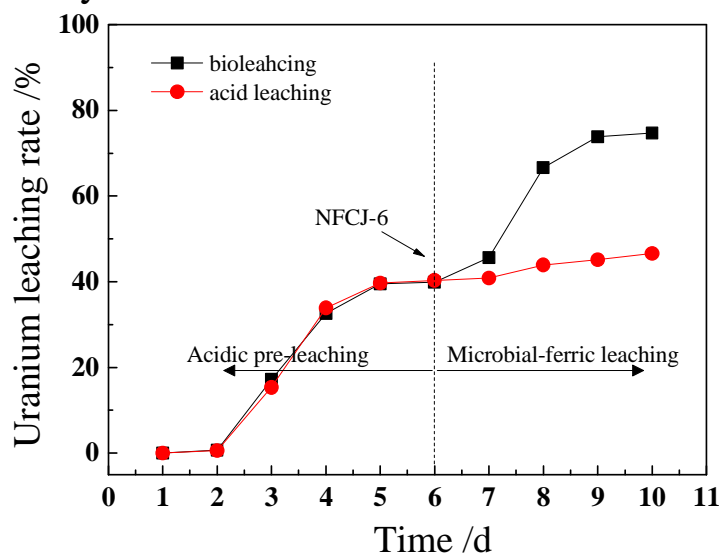

Fig.4 The variation of uranium leaching rate in leaching process

\section{Conclusions}

Through the experiment, the domestication effect of fluoride-resistant bacteria was verified, and it can still work normally under the condition of fluoride ion concentration as high as $600 \mathrm{mg} / \mathrm{L}$. compared to acid leaching, the uranium extraction rate in the bioleaching can reach $74.71 \%$, which exceeded more than $28 \%$.

\section{Acknowledgements}

This work was financially supported by the National Natural Science Foundation of China (No.51404031). 


\section{References}

[1] Y.Q. Cai, J.D. Zhang, Z.Y. Li, et al. Outline of uranium resources characteristics and metallogenetic regularity in China. Acta Geologica Sinica, Vol.6 (2015), p.1051

[2] A. Mishra, N Pradhan, R.N. Kar, et al. Microbial recovery of uranium using native fungal strains. Hydrometallurgy,Vol. 1-2 (2009), p. 175

[3] Y.D. Wang, G.Y. Li, D.X. Ding, et al. Factors influencing leaching of uranium ore by organic acids from Aspergillus niger. CIESC Journal, Vol. 5 (2012), p.1584

[4] L.Y. Ma, X.J. Wang, J.M. Tao, et al. Differential fluoride tolerance between sulfur- and ferrous iron-grown Acidithiobacillus ferrooxidans and its mechanism analysis. Biochemical Engineering Journal, (2017), p.59

[5] L. Guneriusson, A. Sandstrom, A. Holmgren, et al. Jarosite inclusion of fluoride and its potential significance to bioleaching of sulphide minerals. Hydrometallurgy, Vol. 1-2 (2009), p.108

[6] M. Dopson, A.K. Halinen, N. Rahunen, et al. Silicate mineral dissolution during heap bioleaching, Biotechnol. Bioeng,Vol. 99 (2008), p.811 